\title{
Public participation in land control: national and foreign experience
}

\author{
Rano Turdiboeva ${ }^{1, *}$, and Matluba Mirzaabdullaeva ${ }^{2}$ \\ ${ }^{1}$ Tashkent State Agrarian University, University str., 2, Tashkent province, Uzbekistan, 100140 \\ ${ }^{2}$ Tashkent State University of Law, Sayilgoh str., 35, Tashkent, Uzbekistan, 100047
}

\begin{abstract}
The growth of the world's population and the rapid development of the economy are leading to an increase in the demand for agricultural products from year to year. This, in turn, increases the demand for limited natural resources - water and land resources, especially land for agricultural purposes. In such a complex environment, the rational and efficient use of land, increasing productivity by improving the reclamation and fertility of the soil is a requirement of the times. The growing demand for land in society makes it necessary to develop and implement measures to protect land. Land protection is closely related to land control, which is ensured by land control. In this study, the study was conducted in terms of public participation in land control in the field of agricultural land use. At the same time, the foreign experience in the field and the national legal framework of the Republic of Uzbekistan were compared. The article also discussed the goals and objectives of land control. The authors have scientifically and legally studied the participation of the public in land control, the advantages, subjects, objects and forms of public control. The article also examines scientific research on land control and public control. As a result of studying the system of legislation of the Republic of Uzbekistan on land control, the authors systematized the procedures aimed at ensuring public participation in the field. Prospects for the application of foreign experience in the implementation of public land control were also considered. In addition, the scientific and theoretical basis for the rational use of land resources and their protection in achieving the strategic goals of agricultural development of the Republic of Uzbekistan for 2030 has been developed.
\end{abstract}

\section{Introduction}

Land is a limited and non-renewable natural resource. The role of the earth in the life of the state and society is incomparable. In particular, agricultural lands play an important role in providing the population with food and industrial raw materials. The Food and Agriculture Organization of the United Nations (FAO) determines the suitability of land for agriculture in terms of its ability to produce the crop needed for a basket of crops [1]. Land resources are crucial in agricultural development, poverty alleviation, food security, adaptation to

\footnotetext{
*Correspondent author: ranotur@mail.ru
} 
climate change, overcoming its consequences, as well as ensuring the well-being of millions of rural people.

According to UN forecasts, the world's population could reach 10 billion by 2050 , complicating the task of providing adequate and quality food to the world's population in the face of increasing degradation of agricultural land and declining water resources. At a time when 2.6 billion, or more than $33 \%$, of the world's more than 7.7 billion people live on agriculture, $52 \%$ of agricultural land has been severely degraded, resulting in a significant decline in soil fertility. As a result of drought and desertification, 12 million hectares of land ( 23 hectares per minute) go out of use every year. These problems, which are typical of other countries, have not bypassed Uzbekistan. The total area of agricultural lands in the Republic of Uzbekistan is 44,892.4 thousand hectares, the total area of agricultural lands is 20,236.3 thousand hectares, including arable lands - 3,988.5 thousand hectares, perennial forests - 383.1 thousand hectares, gray lands - 76 thousand hectares. hectares, hayfields and pastures - 11,028.3 thousand hectares, other lands - 4,760.4 thousand hectares. Agricultural lands belong to fertile lands and are the main means of ensuring national wealth, agricultural production and food security of the country. Due to the rapid growth of the country's population, the transfer of agricultural land and the sharpening of the impact of global climate change, the area of irrigated land per capita has decreased by $24 \%$ (from 0.23 hectares to 0.16 hectares) over the past 15 years. As a result of irrational use of agricultural lands for many years, natural soil fertility and crop yields are declining, the quality of crops is deteriorating, and environmental pollution is increasing. In particular, the content of mobile phosphorus in $93 \%$ of irrigated arable lands, the amount of exchangeable potassium in $68.3 \%$, and the amount of humus (humus) in $79.3 \%$ fell below average [3]. Only $20.7 \%$ of the 20.2 million hectares of agricultural land are irrigated. It is projected that irrigated land areas could shrink by another 20 to 25 percent over the next 30 years.

In addition, in the land practice of the republic there are frequent cases of violation of land legislation by land users. This, in a sense, leads to a decrease in land area for agricultural purposes, a decrease in soil fertility. It is not possible to solve the problems listed above without taking measures to protect land resources and applying optimal ways of their rational and efficient use. Therefore, in the period up to 2030, the Concept of Environmental Protection of the Republic of Uzbekistan was developed and the task of improving state control in the field of environmental protection and rational use of nature, as well as the system of environmental monitoring [5].

State and public measures aimed at preventing, detecting and limiting violations of the legislation in the field of environmental protection and rational use of natural resources, including environmental control and control over the rational use of nature; is a system of measures [6]. Land is an object of environmental control as a natural resource. Control over land use and protection is an integral part of environmental control [7]. Article 83 of the Land Code defines the main tasks of control over land use and protection.

Accordingly, ensuring compliance of legal entities and individuals, public administration bodies, local public authorities with the requirements of the legislation is the main task of control over the use and protection of land [8]. Public control over land is carried out by citizens' self-government bodies, the media, non-governmental non-profit organizations, citizens of the Republic of Uzbekistan, and they are the subjects of public environmental control, in turn, land control. 


\section{Materials and methods}

This article includes an analysis of legislation and scientific and theoretical sources as a doctrinal study. This article examines the scientific concepts related to the field, the views, conclusions and opinions of theoretical scholars. Legislation in the field of environmental and land control is also analyzed comparatively. The article began with a study of the basic concepts of the subject, continued with the development of these concepts, and ended with the conclusion that the improvement of existing mechanisms, ways to solve problems. The implementation of these conclusions will serve to clarify the place and role of land resources in ensuring the sustainable development of agriculture, to achieve the goals of food security through the protection of agricultural lands.

\section{Results and discussion}

Organization and management of land use is an important socio-political direction of state activity. Land control has a special place among the measures to organize and improve the management of land resources. Today, land control has not lost its relevance in the conditions of our republic. In the transition of our society to a market economy, land control is becoming more important than ever [9].

There are many claims in the legal and economic literature about the effectiveness of the market in the self-regulation of land relations [10]. According to the views expressed, it is clear that landowners organize the rational and efficient use of land for economic gain, in which case there is no need to control them. Of course, these views are controversial.

According to the Inspectorate for Control over the Agro-Industrial Complex under the Cabinet of Ministers of the Republic of Uzbekistan, in January-October 2020, the control measures carried out by Uzagroinspection on the rational use and protection of agricultural lands violated 27,673 hectares in 5,183 cases have been identified. In particular, in 1369 cases individuals and legal entities arbitrarily occupied 2123 hectares of land, built illegal housing and other structures, in 3414 cases 17561 hectares of land were used or rendered unusable for other purposes, in 33 cases 368 hectares Violations of land allocation procedures by district khokimiyats (regional control organization), use of 100 hectares of used land without timely return in 70 cases, arbitrary deviation from 7521 hectares of infarm land management projects in 297 cases and violation of state land cadastre data were revealed.

In order to eliminate these violations and take measures, 3,056 warning letters were sent to the perpetrators and landowners, 66 mandatory instructions were issued to eliminate them, and 360 submissions were submitted to local authorities.

In addition, in accordance with the relevant articles of the Code of Criminal Procedure of the Republic of Uzbekistan, 2390 documents on violations were sent to the courts for consideration, and in 263 cases to law enforcement agencies. [11].

This information about the condition of our lands proves the opinion of Yu.G. Jarikov that "all land users are responsible for their actions before the law and the state". [12]. Land is public property. As in many developed countries, the state can achieve the harmonization of the interests of private owners with the interests of society as a whole through economic incentives for rational businesses, the development of effective measures to combat violations of land legislation, strict state control over land use and protection and a clear system of state land control possible. For example, the constitutions of Germany, the Czech Republic and Poland enshrine the norm on the obligation to use land efficiently. The Bavarian constitution states that the distribution and use of land is under state control; agricultural lands serve the whole people; the acquisition of land used in agriculture and 
forestry will depend on the recipient proving his ability to cultivate these lands, and such lands cannot only serve as capital investment [13].

The scientific literature states that land control performs three main functions as a legal measure: prevention of land offenses, ie prevention of illegal impact on land plots that have not yet begun; obtaining information, ie collecting information about the object under control and bringing to justice those who violate land legislation [14].

The classification of land control types can be done according to several criteria. State land control and public land control can be divided into subjects exercising land control. Today, civil society institutions are becoming one of the most important means of ensuring effective interaction of citizens with the state through the implementation of public control [15].

In the system of environmental control, public environmental control is an effective link. Because if there is an environmental problem in a certain area, the public will be informed first, and the local population will be interested in solving this problem. This, in this sense, determines the effectiveness of public environmental control.

General aspects of public oversight include:

- not introduced by the authorities;

- not legally or binding;

- public administration bodies cannot be the subject of public control;

- on behalf of the community and citizens.

There are also specific aspects of public control: first, public control manifests itself as a form of influence on society or its individual institutions, integrating the interests and needs of society members into the general social will;

second, public control is a key means of balancing the interests of different social groups and preventing conflicts of interest;

third, it is a way of uniting and coordinating the desires and aspirations of society in solving the most pressing issues;

fourth, public control ensures the implementation of social norms, identifies violations and carries out activities ranging from condemning them to ensuring the application of coercive measures;

fifth, the exercise of public control is a power inherent in any society and is one of its main institutions [16].

The legal basis of public environmental control, in particular land control, is the Law of the Republic of Uzbekistan "On Public Control" and "On Environmental Control" [17].

It should be noted that in the legislative practice of some developed foreign countries, such as the United States, Great Britain, Germany, France, there is no separate law on public control. Nevertheless, public scrutiny is reflected in other legislation. These states are in legislative practice

The subjects of public control are mainly citizens, public councils, scientific institutions, NGOs and the media. In Denmark, the parliament, deputies and special commissions are also subject to public scrutiny [18].

According to the Law of the Russian Federation "On the Foundations of Public Oversight in the Russian Federation", the following are the subjects of public oversight: 1) the Public Chamber of the Russian Federation; 2) the Public Chamber of the subjects of the Russian Federation; 3) public chamber of municipal organizations; 4) the Public Council under the federal bodies of executive power, the Public Council under the legislative (representative) and state executive bodies of the subjects of the Russian Federation (Article 9 of the Law). It is also possible to establish a public oversight commission, public inspection, public oversight group and other organizational structures of public oversight to carry out public oversight in cases and in the manner prescribed by the legislation of the Russian Federation [19]. 
In the Republic of Kazakhstan, there is a law "On Public Councils", according to which public councils are an advisory body, oversight body established in the ministries, central executive bodies.

In foreign countries, a number of forms of public control over the activities of state power are developed and widely used in everyday activities. At the same time, it should be noted that in far abroad countries, the concept of "civil control" is used instead of the concept of "public control" [15].

The "Model Regulations on the Procedure for Implementing Public Environmental Control" approved by the Resolution of the Cabinet of Ministers of the Republic of Uzbekistan No. 287 of October 8, 2015 plays a special role in regulating public environmental control [20]. Article 9 of the Regulation stipulates that specially authorized state bodies in the field of environmental control, state and economic administration bodies, and local state authorities cooperate with citizens' self-government bodies, nongovernmental non-profit organizations and citizens on issues of public environmental control.

Cooperation between the subjects of public environmental control and government agencies on environmental control is also reflected in Articles 11-12 of the Law "On Environmental Control". The close interrelationship between state control and the public suggests that these two types of control are not interchangeable, while at the same time providing interaction for the sole purpose of control. This connection is important in identifying disputes between the state government, its central office, and citizens. While public authorities often use information provided by public oversight bodies in their activities, public oversight performs its function by applying to the relevant public oversight bodies. The interaction between the state and public control serves to provide the society and the authorities with objective information about the existing and pending conflicts in the field of public administration and to find their optimal solution. This will help to find new ways to develop and improve existing systems of government that meet the needs of civil society and democratic statehood [21].

The activity of the Council of Farmers, Dehkan Farms and Landowners of Uzbekistan plays a special role in the implementation of public land control. Resolution of the President of the Republic of Uzbekistan dated October 10, 2017 No PD-3318 "On organizational measures for further development of farms, dehkan farms and landowners" as one of the main tasks of the Council of Farmers, Dehkan Farms and Landowners of Uzbekistan implementation has been identified [22]. According to him, until February 1 of each year, the council, together with the chairmen of citizens' self-government bodies, preventive inspectors of law enforcement agencies, will go from house to house and register the arable lands of farmers and landowners in the region. and divides into parts intended for sale, organizes public control over the conclusion of contracts for the supply of products, complete and quality planting of crops, the timely implementation of agrotechnical measures.

Under the public control of the Council, a threefold increase in the land tax rate is applied to landowners who have not unreasonably planted or beautified agricultural crops in the backyards of land plots allocated for individual housing construction and improvement, housing for farming the right of landowners who have not planted agricultural crops on the land plots granted without the right of construction to the land plot shall be terminated in accordance with the procedure established by the legislation.

Public land control carried out by the Council of Farmers, Dehkan Farms and Landowners of Uzbekistan is also a type of public environmental control, which is carried out in accordance with the provisions of the Model Regulations on the procedure for public environmental control. According to it, public environmental control is the monitoring of the state of the environment and changes in its economic and other activities, compliance 
with the requirements of legislation in the field of environmental protection and rational use of natural resources by legal entities and individuals, state environmental programs and other environmental programs. , to participate as an observer in the implementation of state, departmental and industrial environmental control, to hear information and reports of the heads of relevant public authorities, enterprises, institutions and organizations on environmental protection, sanitation, landscaping, and public environmental examination.

In particular, in foreign countries, abrogative referendum (civil veto) (Switzerland), collaboration (USA), civic initiative (France, Germany, Italy), public (people's) legislative initiative (law-making) (USA, Germany, Spain, Italy, Latvia, Lithuania, Poland, Romania, Slovenia, Switzerland), public oversight commissions and committees (Belarus, Kazakhstan, Kyrgyzstan), mass media (USA, EU), public councils (chambers) (Austria, USA, Armenia, Brazil, Greece, The Netherlands, Poland, Kazakhstan, France), online petition (USA, EU), Councils on Minority Affairs (Czech Republic), Penitentiary Visitors Council (UK, France), Civil Audit (USA) various forms of public control are used (Figure 1) $[15]$.

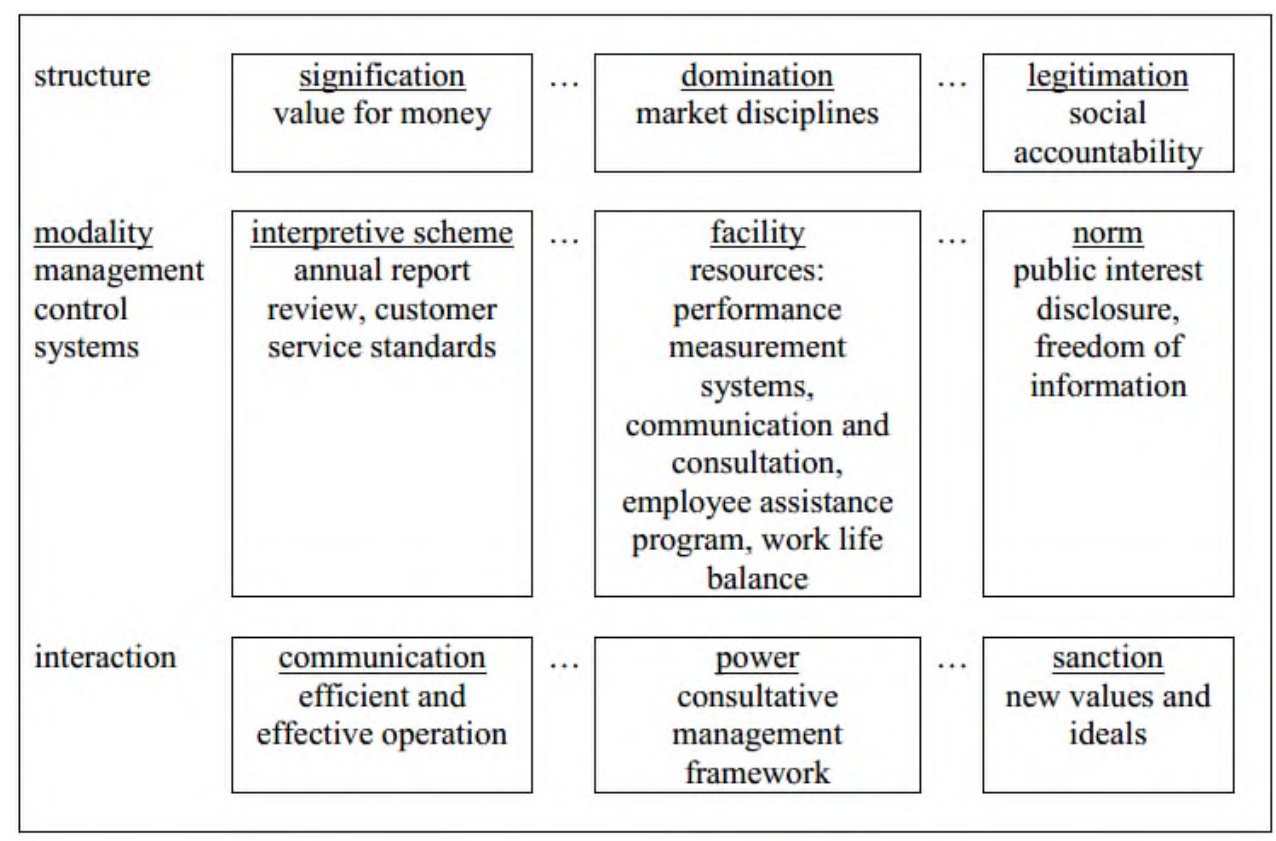

Fig. 1. Public sector management control systems.

Lawyer, ecologist, scientist prof. J.T. Kholmuminov noted that "the effectiveness of environmental and legal control can be achieved only with the correct use of forms of control" [23].

The Model Regulation "On the Procedure for Implementation of Public Environmental Control" stipulates that the results of public environmental control may be formalized in the prescribed manner through the issuance of a reference or information.

Information or reference on the results of public environmental control:

-when environmental control is carried out by citizens 'self-government bodies or representatives of non-governmental non-profit organizations, it shall be approved by the chairman of the relevant citizens' self-government bodies or the head of the nongovernmental non-profit organization;

-when environmental control is carried out by a citizen through self-invitation, the results of control are confirmed by the citizen. 
Information or reference on the results of public environmental control shall be sent by citizens' self-government bodies and non-governmental non-profit organizations to specially authorized state bodies in the field of environmental control, other state bodies, as well as heads of organizations for consideration.

The following are the forms of implementation of the results of public environmental control:

-to inform specially authorized state bodies, local state authorities on the results of public environmental control;

-to make proposals to government agencies to take appropriate measures in cases of violations of the legislation in the field of environmental protection and rational use of natural resources.

Notification of specially authorized state bodies, local state authorities on the results of public environmental control may be in the form of oral, written and electronic appeals (applications, proposals or complaints) submitted in the prescribed manner.

Appeals may be accompanied by previous decisions (or copies thereof) of citizens' selfgovernment bodies, non-governmental non-profit organizations or citizens on the merits of these appeals, as well as other documents required for consideration of appeals, including photos, audio and video materials.

The third paragraph of Article 84 of the Land Code stipulates that "nature protection societies, scientific societies and other public associations, as well as citizens shall assist state bodies and citizens' self-government bodies in exercising control over land use and protection." In our opinion, this statement of the law does not meet modern requirements and contradicts the essence of the laws of the Republic of Uzbekistan "On Public Control" and "On Environmental Control". These laws recognize nature conservation societies, scientific societies and other public associations, as well as citizens as independent subjects of public control. This requires an editorial review of this provision of the Land Code and its adaptation to the content of the above legislation.

It can be seen that land control plays an important role in increasing land use efficiency. The goal of the ongoing reforms in our country is to join the ranks of modern democracies that are comprehensively developed, free and prosperous, the rule of law. This has been set as a strategic goal for our state and people. Of course, the effectiveness of such laws will not give the expected result if the most perfect laws adopted in any developed society are not studied and followed by the people. For the effectiveness of laws to be high, members of society must have a high level of legal awareness, legal culture, legal literacy. In addition, the socio-political activity of members of society, citizens should be high, and citizens should feel a sense of involvement in the reforms in society.

In particular, the cases listed are one of the most important conditions in the implementation of public land control. This is because public land control must be done in a way that is understood by the community. Resolution of the Cabinet of Ministers No. 287 of October 8, 2015 approved the "Model Regulations on the Public Inspector of Environmental Control" [24]. A citizen of the Republic of Uzbekistan who has undergone special training in the prescribed manner and has the right to participate in environmental control may be a public inspector of environmental control. Thus, participation in the implementation of public control of land requires citizens to be active in socio-political processes, have a high level of legal awareness, legal culture, and legal literacy.

\section{Conclusions}

In the course of this research, the following conclusions were drawn:

-granting land users the right to pay the established land tax at the previous rate for 5

years in case of increase of soil fertility (score quality); 
-application of the increased amount of the land tax rate for the current tax year in case of decrease in points quality as a result of failure to take measures to increase soil fertility specified in the business plan;

-in order to support and encourage public participation in land control, it is advisable to establish a system of financial incentives in the amount of one to three times the minimum wage for citizens who timely and accurately inform the special authorities about land violations.

It is also necessary to pay attention to ensuring the right to receive cadastral information on land plots, ie the right to receive information, when conducting land control by public representatives.

\section{References}

1. The State of the World's Land and Water Resources for Food and Agriculture. Management of systems at risk, 25 (Food and Agriculture Organization of the United Nations (Rome) and Ves Mir Publishing House, Moscow, 2012)

2. M. S. Yusupov, Scientific electronic journal "Economy and Innovative Technologies", 2, $66(2020)$

3. Decree of the President of the Republic of Uzbekistan No. PF-5742 "Concept of effective use of land and water resources in agriculture" dated June 17 (2019)

4. Decree of the President of the Republic of Uzbekistan No. PF-5853 "Strategy of agricultural development of the Republic of Uzbekistan for 2020-2030" dated October 23 (2019)

5. Decree of the President of the Republic of Uzbekistan No. PF-5863 "Concept of Environmental Protection of the Republic of Uzbekistan for the Period up to 2030" dated October 30 (2019)

6. O. YU. Ganyukhina, Ecological control is the basis of management of natural resources in the Republic of Uzbekistan and the Russian Federation, 177 (2014)

7. R. Kenjaev, Legal regulation of the use and protection of natural resources in business activities, 78 (TSUL Publishing House, Tashkent, 2011)

8. N. K. Skripnikov, Management in the field of land use and protection, 77 (TSUL Publishing house, Tashkent, 2007)

9. U. Mukhtorov, In E3S Web of Conferences, 244, 03013 (2021)

10. S. Gromov, Land Bulletin of Russia, 1, 41 (2000)

11. A. V. Serkov, Rural life, 5, 32-33 (2002)

12. Data on Land Normatives by the Local Governmental Administration - Khokimiyats of Uzbekistan (2020)

13. S. A. Bogolyubova, E. L. Mininoy, Agrarian and ecological legislation in Russia and CIS countries, 91 (1999)

14. A. I. Popov, Regional policy in Russia: problems of state management, 162 (1999)

15. N. V. Gagarinova, Management of land resources, 160 (Krasnodar: KubGAU, 2017)

16. M. B. Usmonov, M. R. Mirzaabdullaeva, G. SH. Uzakova, Theoretical problems of land law in Uzbekistan, 127 (Tashkent: TSU Publishing House, 2011)

17. M. M. Mamasiddikov, A. A. Otajonov, Development and improvement of mechanisms for establishing effective public control over the activities of government agencies in our country, 7 (Tashkent, Lesson press, 2020) 
18. A. Jalilov, U. Muhammadiev, Q. Juraev, Fundamentals of Civil Society, 129 (2015)

19. Law of the Republic of Uzbekistan "On Environmental Control", No. 52, Article 688 (2013);

20. M. M. Mamasiddiqov, S. S. Odilov, Proceedings of the scientific-practical conference "Development and improvement of effective mechanisms of public control over the activities of government agencies in ensuring human rights in our country", 22-31 (2018)

21. Law of the Republic of Uzbekistan "On Public Oversight", National Database of Legislation, No. 03/18/474/1062, April 13 (2018)

22. Collection of Legislation of the Republic of Uzbekistan, No. 41, Article 526 (2015)

23. M. R. Mirzaabdullaeva, Land control in agriculture: law and practice, 90 (Tashkent: TSU, 2020) 